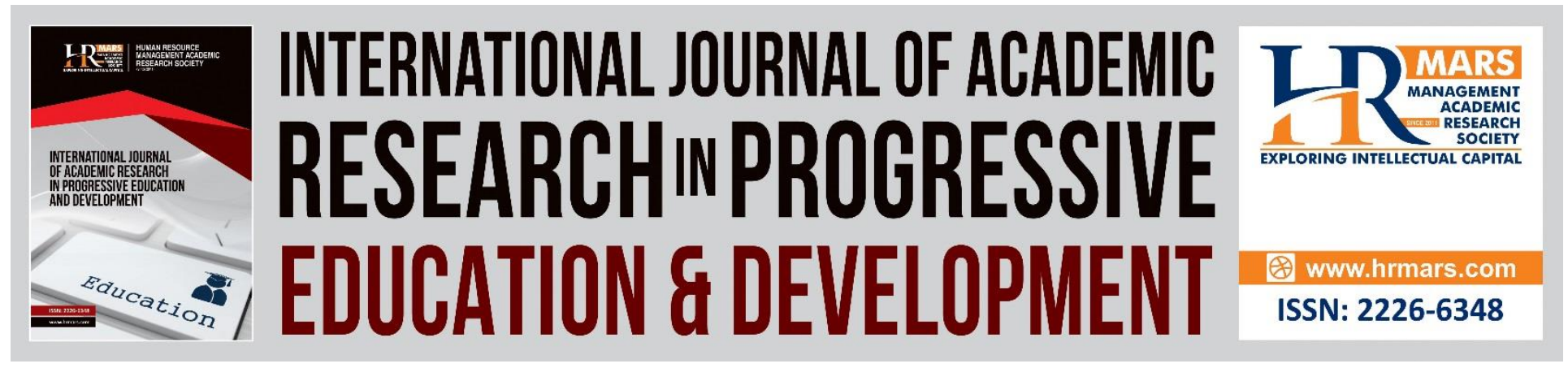

\title{
Customer-Driven Business Information provision in Malaysian Government Agencies' Library
}

Noor Zaidi Sahid, Siti Arpah Noordin, Mad Khir Johari Abdullah Sani

To Link this Article: http://dx.doi.org/10.6007/IJARPED/v7-i3/4354 DOI: $10.6007 /$ IJARPED/v7-i3/4354

Received: 06 June 2018, Revised: 26 June 2018, Accepted: 11 July 2018

Published Online: 20 July 2018

In-Text Citation: (Sahid, Noordin, \& Sani, 2018)

To Cite this Article: Sahid, N. Z., Noordin, S. A., \& Sani, M. K. J. A. (2018). Customer-Driven Business Information provision in Malaysian Government Agencies' Library. International Journal of Academic Research in Progressive Education and Development, 7(3), 137-149.

Copyright: (C) 2018 The Author(s)

Published by Human Resource Management Academic Research Society (www.hrmars.com)

This article is published under the Creative Commons Attribution (CC BY 4.0) license. Anyone may reproduce, distribute, translate and create derivative works of this article (for both commercial and non-commercial purposes), subject to full attribution to the original publication and authors. The full terms of this license may be seen at: http://creativecommons.org/licences/by/4.0/legalcode

Vol. 7, No. 3, July 2018, Pg. 137 - 149

Full Terms \& Conditions of access and use can be found at http://hrmars.com/index.php/pages/detail/publication-ethics 


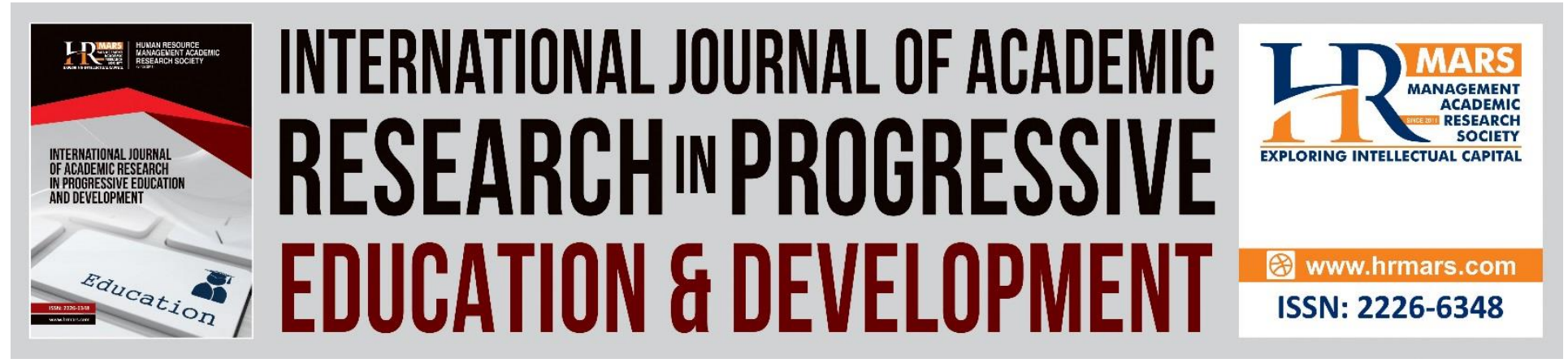

\title{
Customer-Driven Business Information provision in Malaysian Government Agencies' Library
}

\author{
Noor Zaidi Sahid*1 Siti Arpah Noordin*2 Mad Khir Johari \\ Abdullah Sani*3 \\ 1, 2, 3 Faculty of Information Management, Universiti Teknologi MARA, MALAYSIA. \\ Email: zaidisahid@salam.uitm.edu.my
}

\begin{abstract}
This qualitative research develops a Customer-Driven Business Information Provision (CDBIP) model for the Malaysian Government Agencies' library. The model has been drawn up according to the perspective of the government agency's library in Malaysia which employs two dimensions: design and management of a customer-driven service system and the fostering of good governance. This model elicited five (5) themes of design and management of a customerdriven service system: customer identification, customer needs survey, service system design, service delivery, and service recovery. In this comprehensive model, the best practices of government agency's libraries are empirically examined the types of CDBIP activities that has established; and how they can be established. Analysis and findings have drawn from the data collected from the multiple case study that involved twelve (12) librarians from twelve (12) selected government agency's libraries. The findings of this study have implications for the model, policy, and practices on how customer-driven concept can adopted by libraries and other government agencies.
\end{abstract}

Keywords: Business Information, Customer-Driven, Information Provision, Malaysian Agencies' Library, Information Management, Library Science

\section{Introduction}

Ascertaining the customer needs and wants, and delivering the desired satistaction effectively and efficiently are the best ways of serving customers. Customer-driven implies that goods or services should be assured and impacts resolved with the most valuable customers in mind. To be customer-driven, service providers need to do more (e.g. know which customer is affected, what their actual service experience is and how valuable the customer is to their service) (Amdocs, 2016). All of which brings unprecedented changes to the public services. Libraries, therefore, are under pressure to satisfy various stakeholders, increase efficiency, effectiveness and quality services, achieve organizational goals and establish a culture of continuous improvement. 
Customer-driven has been defined in different ways in the literature (Agrawal, \& Rahman, 2015; Kohli \& Jaworski. 1990; Webster, 1988). Customer-driven is the knowledge of customers and target customers to be able to create superior value consistently superior to them (Raie et al., 2014). While Spector (2017) refer customer-driven as the organization's needs and ability to identify, analyze, understand and respond to customer needs. In information provision context, this approach must be driven both by the providers and their customers so that it will help users to always access quality information.

Kuusisto and Riepula (2011) argue, the interaction between a customer, and service provider is perhaps the most basic feature in service activities. They then added that customer involvement in the provision of services is something that must be done. This shows that organizations that interact with customers will have an advantage in terms of the core competencies of their services. Similarly, Prakash et al., (2016) assert that customer orientation is the key to organizational performance. This statement has been proven empirically through a study carried out by Jaakkola, (2015), McColl-Kennedy et al., (2015) and Kuusisto and Riepula (2011).

In most communities, there is a need to access all kinds of BI. Therefore, in principle, the library and information services should be developed in response to the needs of the community. On the other hand, BI providers must also understand the demand and the needs of the customers, their interest and how they value such services. This view is supported by Nwankwo (1995) who denoted that insufficient understanding of customer orientation could lead to a problem. However, Bouthillier (2004) added that many librarians do not perceive such needs as a priority. As a result, the library will face difficulties to serve communities with relevant $\mathrm{BI}$ as expected.

The objective of the paper is to explore the step-by-step analysis of CDBIP being practiced by the Malaysian government agencies' library. In the next section, this objective being translated into the research model and was described in more detail. This model offers an insight to understand how the CDBIP is established at the library. The remainder of the paper is focused on the finding of the study which have implications for the model and practices on how customer-driven concept can adopted by libraries and other government agencies.

\section{Research Framework}

Empirical research on customer-driven varies in context, focus, and findings. The current state of empirical research shows that customer involvement in service provision can be characterized as truly interdisciplinary, involving human-computer interaction, engineering design, organizational knowledge creation theory, marketing and quality management. Consequently, reviewing previous research is difficult. The researcher started with marketing-centered studies and then investigated other disciplines. Previous research about customer involvement in new library service development is limited; therefore, the number of references in this research realm to build from as well as the conceptual variety is reduced. Studies on customer involvement in new product development are not included, since this study should account for the complexity of services related to the new services development in government agencies' library. 
Vol. 7, No. 3, July 2018, E-ISSN: 2226-6348 @ 2018 HRMARS

The literature states a number of strongly allied concepts of customer involvement, namely lead user method (Frambach et al., 2016, Cui \& Wu, 2016; Frow et al., 2015; Olson \& Bakke, 2001), user involvement (Jaakkola et al., 2017; Jouny-Rivier et al., 2017; Cui \& Wu, 2016; Grundy et al., 2016; Biemans et al., 2016;), and customer participation (Chang, \& Taylor, 2016; Cui \& Wu, 2016; Dong et. al., 2015). Several different parameters are used to grasp and describe the concepts, namely degree of customer involvement (Biemans et al., 2016; Martin \& Horne, 1993; Voss, 1985), behavioral and personal characteristics of users (Tukker, \& Tischner, 2017; Barrett, 2015; Morrison et al., 2011), objectives of customer involvement (Biemans et al., 2016), the role of customers in the service innovation process (Koskela-Huotari et al., 2016; Barrett, 2015 Frow et al., 2015), modes and methods of customer involvement (Koc et al., 2017; Mustak et al., 2016; Dong et. al., 2015; Dong 2015), users as source of innovative ideas (Puga-Leal, \& Ormazabal, 2017; Schemmann, et al., 2016; McColl-Kennedy et al., 2015), antecedents to customer involvement (Li et al., 2015; Greer, \& Lei, 2012), and customer involvement and new service success measures (Chang \& Taylor, 2016; Carbonell et al., 2009).

The review of literature reveals a limited number of qualitative studies on the constructs central to this study. Most of these studies are quantitative in nature. Furthermore, despite the prevalent call of studying customers in the context of organizational learning (Matthing et al., 2004), only one work exists that clarifies the process of customer knowledge co-creation. Blazevic and Lievens's (2008) study imparts how virtual customer communities co-produce knowledge valuable for creating new electronic services.

CDBIP model is a comprehensive model that was develop through analysis of best practices of $\mathrm{BI}$ provisions in Malaysia. The model is adapted from the model produced by Chen et al., (2004) and Jiang and Chen (2002). However, various elements have been set aside to take into account the cultural and governance differences of the government agencies in Malaysia. Therefore, the model can be used as guidance by any parties plan to develop a customer-centric BI services. This research made a significance contribution to the body of knowledge, especially in the library and $\mathrm{BI}$ field thus it is suitable for replication and expansion.

First of all, the box of organizational strategic focus is placed on the left-hand side. It indicates the driving forces that govern a library to develop and manage a $\mathrm{BI}$ provision. In this context, the organization's strategic focus includes the objectives, mission and vision of the organization. In addition, policies, guidelines and regulations of the organization are also part of the organization's strategic focus.

The dotted-line box of the model, which is the kernel of this study, indicates the customer-driven design and management. It contains a five-stage sequence of a CDBIP namely:

i. Customer identification - the library identifies its customers;

ii. Customer-needs survey - the library focuses on the customer needs and customer voice;

iii. Services system design - the library develops the service system and processes to meet the customer needs;

iv. Service delivery - the staff in the library delivers services to customers; and

v. Service recovery - the library has an effective mechanism to deal with customer complaints. 


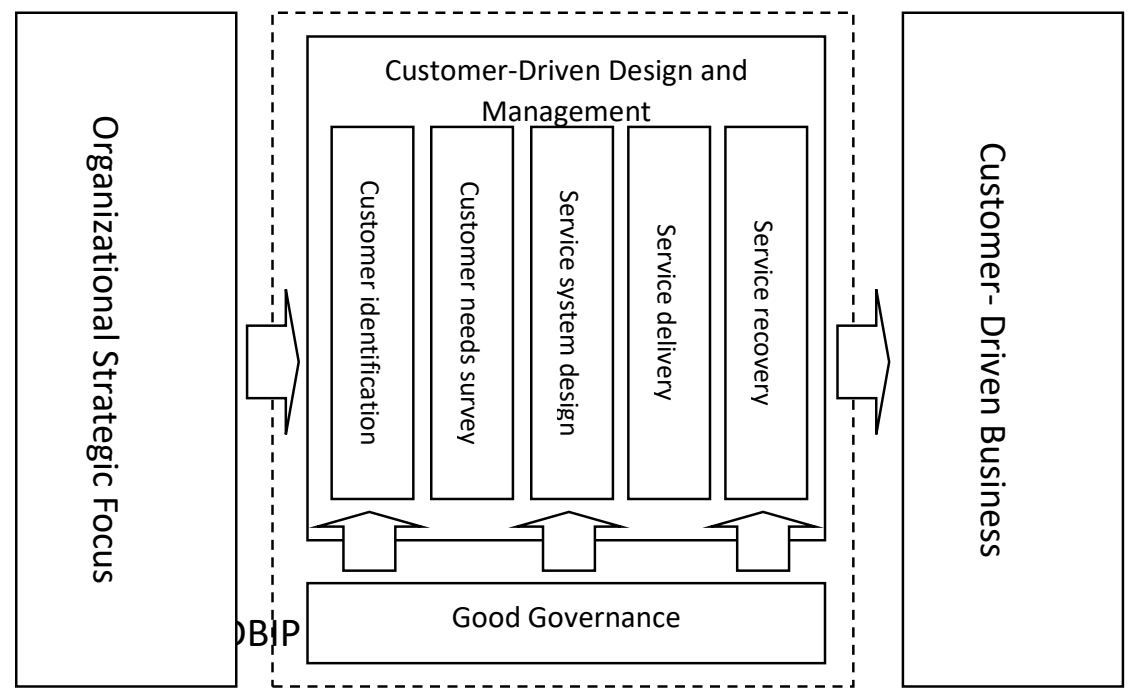

The other dimension of this model is the element of good governance. The principles of good governance will assist to improve the public service delivery system (Fung, 2015). This element has been widely acknowledged in literature on the importance and relevance of governance in the public service (Bovaird, 2016, Niza, 2015; Tummers, 2015; World Bank, 1991). In this framework, a good governance is the enhancement element of efficiency and performance of the public sector.

CDBIP is placed on the right-hand side which indicates the outcomes of the process. In this context, according to Okello-Obura and Malovu (2011), the provision of BI must be focused and precise as well as following the user's requirements. The outcomes of the model can be considered as customer satisfaction. This coincides by Jiang and Chen's (2002) statement, which indicates that the more customer-driven an organization is, the better service quality and customer satisfaction can be achived.

\section{Research Design}

Since the focus of the study is to explore in-depth situation of the CDBIP, a qualitative approach is the most appropriate. To achieve the research objective, a multiple case study approach was chosen. According to Chen et al., (2004), Zeppou and Sotirakou, (2003) and Nwankwo (1995), customer-driven was originated from an industry that is basically a practical arena. Thus, to examine the customer-driven activities from the best practices, becomes a right way.

As the data collection method is a semi-structured interview, an interview guide was prepared for the purpose. Using the purposive sampling techniques, librarians involved in providing BI services to customers were invited to participate as informants. A total of twelve (12) qualified librarians represent (12) twelve library participated in this study. To create a casual interview session, the first session of the interview aimed at establishing rapport as suggested by Pinsky (2015). Subsequently, the researchers explained the purpose of the interview and presented the informed 
Vol. 7, No. 3, July 2018, E-ISSN: 2226-6348 @ 2018 HRMARS

consent form for the respondents to complete. The respondents were assured of the confidentiality of their responses and profiles. In order to ensure that the interview data were accurately captured, the entire interview sessions were digitally recorded after obtaining the approval and consent from the respondents. For validation purposes, notes were written down manually. In order to demonstrate the credibility of the data, this research employed the member checking approach by sending a copy of the interview transcript to each respondent and their organization for validation as suggested by Lincoln and Guba (1985).

Thematic analyses were then conducted to analyze the qualitative data. According to Boyatzis (1998) in Braun and Clarke (2006), thematic analysis is a qualitative analytic method for identifying, analyzing and reporting patterns (themes) within the data. It minimally organizes and describes the data set in (rich) detail. There is a discussion in the literature about how to report the prevalence of individual themes within thematic analysis (Braun \& Clarke, 2006). One rationale for reporting prevalence is that it allows researchers to show that the theme 'really' existed within the dataset. Prevalence has been reported either by using terms such as 'the majority of participants' (Meehan et al., 2000) or 'many participants' (Taylor \& Ussher, 2001), or by reporting the numbers of respondents that referred to a theme (Woodward \& Joseph, 2003). However, as Braun and Clarke (2006) noted, the fact that a theme frequently reoccurs does not directly infer its 'keyness', rather the inclusion of a theme should be based on its centrality to the person's own account.

As the data set is relatively small, this research adopted the Zhang and Wildemuth (2016) views, which stated that it would be appropriate to use only the manual analysis method. Braun and Clarke's (2006) approach has been used for this purpose. It includes measures such as: i) becoming familiar with the data; ii) generating initial codes; iii) searching for themes; iv) reviewing themes; v) defining and naming themes; and vi) producing the report.

\section{Findings and Discussions}

The 12 respondents who participated in the interviews provided numerous activities, which reflect the themes of study. Five major phases relating to the CDBIP were found in the 12 libraries. This research will focus on these phases and look at how they are distinct entities yet interrelated to each other.

From the initial overview of the context the data represented, the researcher had constructed a diagram to map the categories emerging from all the texts. The diagram was developed and evolved as the transcriptions were read one by one. This process was considered as the initial overview of the whole story based on what was being told by each respondent. Based on the diagram, five major themes were identified in the participants' experience in BI provision. Within each of these themes two to four further sub-themes (activities) emerged. In keeping with the criteria for good qualitative practice, each theme is described below and the subsequent subthemes are grounded in a minimum of two examples (Chowdhury, 2015).

In Figure 2, there are five phases of CDBIP (Customer identification, customer-needs survey, service-system design, service delivery and service recovery) and 15 customer-driven activities. 


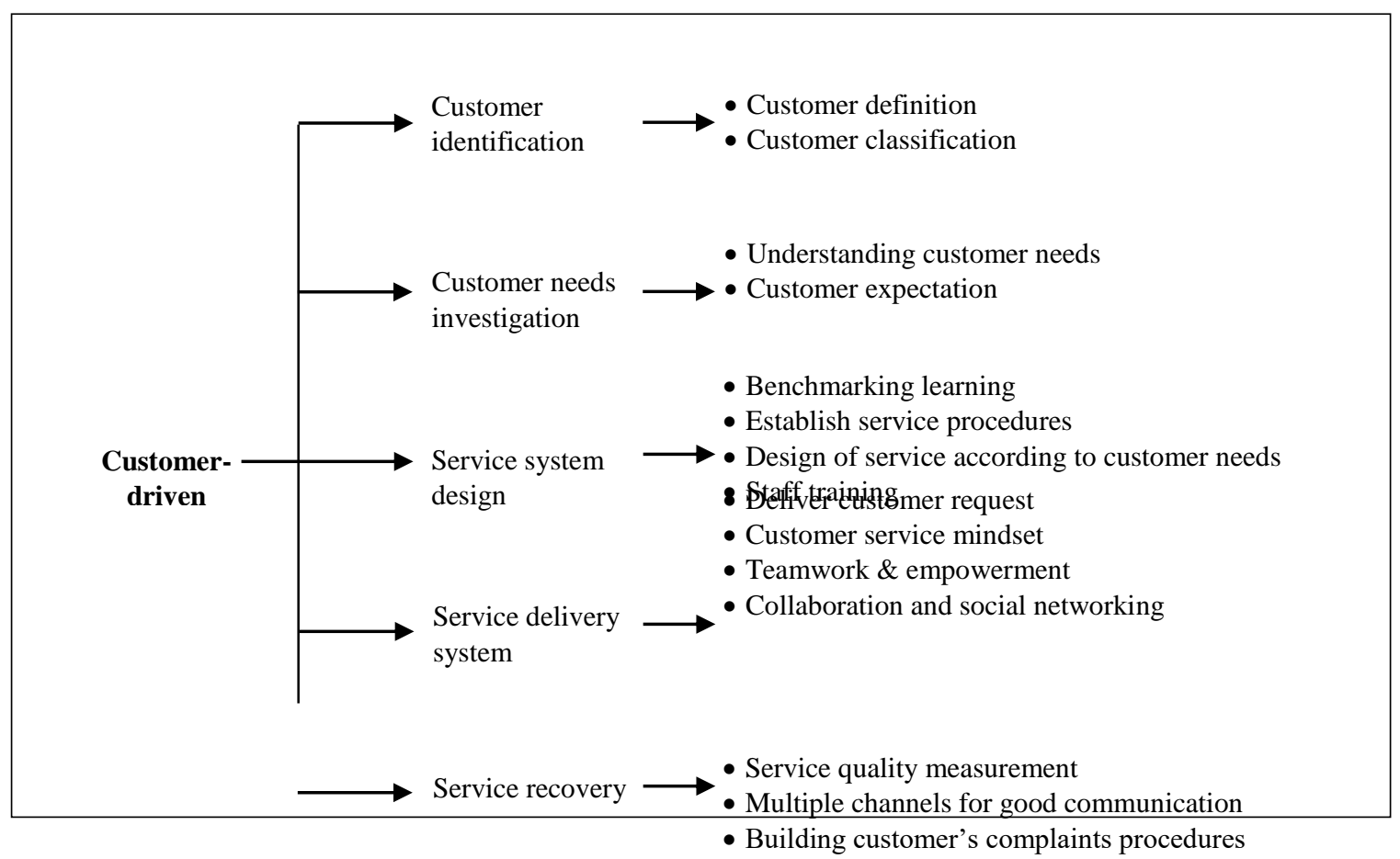

Figure 2 : CDBIP activities

The growing importance of customer-centric element in the process of information provision and their direct or indirect involvement in the activities requires a new approach to users (Krawczyk, 2013). Consequently, there is a need for a redefine the roles of enterprise strategy, and, in particular focusing on the customers' involvement. Customer created demands is an important determinant of activities of contemporary information providers. Therefore, by determining and deciding on the demands for products or services significantly influence the success or failure of the $\mathrm{BI}$ services.

Based on the activities occurred, it is concluded that the CDBIP elements being used in the libraries being investigated, This information could come directly or indirectly from the customers and the application of knowledge, ideas, and ready-made solutions, for the customers to make them as co-creators of the BI services. The CDBIP allows a deeper understanding of customers' information needs and strengthening of their roles in running the activities.

Based on the above findings, this research had determined the ultimate power of the customers in the process of $\mathrm{BI}$ provisions. The voice of the customers define the way information providers identify the needs of the users, mobilize them to think creatively, and use the acquired knowledge to make changes in the services already available in the libraries. Therefore, the libraries should perform appropriate user studies, conduct customer needs and preference analysis. Using the results of the studies, the libraries can make efforts to create and implement 
Vol. 7, No. 3, July 2018, E-ISSN: 2226-6348 @ 2018 HRMARS

the changes, mostly by improving the current services. The conclusion made to discuss this matter include:

- A number of approaches need to be implemented by the libraries of the government agencies in Malaysia. This is in-line with the best practices in consumer-driven services in the Malaysian public sector. The approaches and practices should consider a change in the library philosophy and to place customers either directly or indirectly involved in the provision of $\mathrm{BI}$.

- This study offers new insights on the role of the different stages of customer involvement by advocating the power of customers. The customer involvement is contrary to the previous study, which stated that customers act as sources of new ideas only (LarbigWust, 2010; Kristensson et al., 2004).

- Organizational resources are activated into a better understanding of the customers' needs, allowing skillful responses to the submitted requirements, and delivering what the customers want;

- There is a direct involvement of customers in the provision of $\mathrm{Bl}$;

- Direct or indirect customer involvement in the provision of $\mathrm{Bl}$ is a complex process, which requires a change in thinking, and often a change in a library's strategy.

The findings of this study conclude that the process of customer-driven CDBIP provision includes, at least, the following steps:

- Customer identification Identifying customer information behavior and attitudes concerning the types of their information needs. Classifying library customers according to distinct categories based on pre-determined characteristics.

- Customer needs investigation

Identifying the needs of the customers through their information behavior. At this stage, the use of various research methodologies enables understanding of the users' information needs. Carrying out the processes with the conscious or unconscious of the customers.

- Service-system design

This stage includes the library design and establishing the services/products for the customers. Documenting the procedures of the activities as the standard operating procedures. At this stage, the library can learn from other providers, including through the benchmarking processes.

- Service delivery

It comprises the activities of delivering information services to users. It also includes the readiness and awareness of staff in the provision of services efficiently. The library needs to be creative in the delivery of services to users, including cooperation and linkages with 
INTERNATIONAL JOURNAL OF ACADEMIC RESEARCH IN PROGRESSIVE EDUCATION AND DEVELOPMENT

Vol. 7, No. 3, July 2018, E-ISSN: 2226-6348 @ 2018 HRMARS

external organizations to obtain the necessary information for the users.

- Service recovery

At this stage, the achievement of the services would be measured. The library needs to have a mechanism to receive feedback from users. At the same time, corrective actions would be carried out to enhance the services.

This study concluded the process of information provision on library activities, yet to be carriedout entirely as suggested by Chen et al. (2004) through its COSES model. However, it is found that the libraries had undertaken several activities that contribute to establishing the CDBIP. Although there does not seem to be uniformity of customer-driven activities carried out, some of the concepts that emphasize the management of customer-driven and audits conducted by the government agencies involved indirectly, had in fact acted as a governance of the provision of customer-driven BI.

From these findings, the customer-driven concept had been practiced in the BI provision for all of the libraries being investigated, although they did not adopted specific techniques in identifying their customer information needs. It is certain these libraries tried to meet customer information needs and requirements that are complex and varied.

\section{Conclusion}

In general, this study has explored how CDBIP is being established in the libraries of the agencies in Malaysia. The importance of providing customer-driven information provision represents a new approach in the present-day information services. Increasingly complex information needs and the diverse society make today's information services change their approaches with regard to the involvement of customers in the information provision processes. Therefore, a systematic methodology for designing and managing consumer-driven concept need to be developed so that it becomes an effective guide for the information providers. The literature review found that there are organizations that fail to develop and adopt the concept of customer-driven. This failure among others stems from the gap that exists in interpreting the customers' requirements and needs.

The overall picture that emerges from this study revealed that the customer-driven design and management activities are combined with customer engagements in the provision of information that combines customer engagement. However, the libraries investigated had used a variety of approaches in the provision of BI. This study was able to identify a five-stage sequence of customer-driven design and management, which were adopted by most of the libraries examined. It includes customer identification, customer needs survey, service system design, service delivery, and service recovery. A total of 15 activities, customer-driven design and management have also been identified. The researcher believes that the five-stage sequence of activities that vary according to the stages, will provide guidance to BI providers, particularly for the need to establish systematic customer-driven services.

Given the lack of studies conducted on this issue, this research will provide a clear picture of how CDBIP can be develop. The model will serve as tools for BI providers to manage the concepts that 
Vol. 7, No. 3, July 2018, E-ISSN: 2226-6348 @ 2018 HRMARS

were established. Simpson and Prusak, (1995) claim that research and other types of information-gathering activities are frequently hampered by a poor understanding of what the end-user wants or expects. Therefore, CDBIP model will produce a service or product that can satisfy the needs of users because the model was produce through analyzing the experience of customer-driven BI providers. Finally, this model offers an insight to understand how the CDBIP is established at the library. However, this comprehensive model can also be used to explore other public services that emphasize on customer satisfaction.

\section{Acknowledgements}

The authors wish to thank all respondents who had participated in this survey.

\section{References}

Agrawal, A. K., \& Rahman, Z. (2015). Roles and resource contributions of customers in value cocreation. International Strategic Management Review, 3(1-2), 144-160.

AMDOCS. (2016). Assuring the customer experiance: Defining a customer-driven service assurance strategy. Retrieved September 20, 2015, from http://www.amdocs.com/Whitepapers/General/TheCustomerExperience.pdf

Barrett, M., Davidson, E., Prabhu, J., \& Vargo, S. L. (2015). Service innovation in the digital age: key contributions and future directions. MIS quarterly, 39(1), 135-154.

Biemans, W. G., Griffin, A., \& Moenaert, R. K. (2016). Perspective: New Service Development: How the Field Developed, Its Current Status and Recommendations for Moving the Field Forward. Journal of Product Innovation Management, 33(4), 382-397.

Blazevic, V., \& Lievens, A. (2008). Managing innovation through customer coproduced knowledge in electronic services: An exploratory study. Journal of the Academy of Marketing Science, 36(1), 138-151.

Bouthillier, F. (2004). The provision of business information services in public libraries: a review trends and issues in six selected countries. In Access to Information: Technologies, Skills and Socio-Political Context: 32nd Annual Conference of the Canadian Association for Information Science, May 29 - June 5 2004. Manitoba: University of Manitoba.

Bovaird, T., Stoker, G., Jones, T., Loeffler, E., \& Pinilla Roncancio, M. (2016). Activating collective co-production of public services: influencing citizens to participate in complex governance mechanisms in the UK. International Review of Administrative Sciences, 82(1), 47-68.

Boyatzis, R. E. (1998). Transforming qualitative information: Thematic analysis and code development. Transforming Qualitative Information Thematic Analysis and Code Development. http://doi.org/10.1177/102831539700100211

Braun, V., \& Clarke, V. (2006). Using thematic analysis in psychology. Qualitative Research in Psychology, 3(2), 37-41. http://doi.org/http://dx.doi.org/10.1191/1478088706qp063oa

Callahan, J., \& Lasry, E. (2004). The importance of customer input in the development of very new products. R\&D Management, 34(2), 107-120.

Carbonell, P., Rodríguez-Escudero, A. I., \& Pujari, D. (2009). Customer involvement in new service development: An examination of antecedents and outcomes. Journal of Product Innovation Management

Chang, W., \& Taylor, S. A. (2016). The effectiveness of customer participation in new product development: A meta-analysis. Journal of Marketing, 80(1), 47-64. 
INTERNATIONAL JOURNAL OF ACADEMIC RESEARCH IN PROGRESSIVE EDUCATION AND DEVELOPMENT

Vol. 7, No. 3, July 2018, E-ISSN: 2226-6348 @ 2018 HRMARS

Chen, C., Yu, C., Yang, S., \& Chang, H. (2004). A customer-oriented service-enhancement system for the public sector. Managing Service Quality: An International Journal, 14(5), 414-425. http://doi.org/10.1108/09604520410558010

Chowdhury, M. F. (2015). Coding, sorting and sifting of qualitative data analysis: debates and discussion. Quality \& Quantity, 49(3), 1135-1143.

Cui, A. S., \& Wu, F. (2016). Utilizing customer knowledge in innovation: antecedents and impact of customer involvement on new product performance. Journal of the academy of marketing science, 44(4), 516-538.

Dong, B. (2015). How a customer participates matters:"I am producing" versus "I am designing". Journal of services marketing, 29(6/7), 498-510.

Dong, B., Sivakumar, K., Evans, K. R., \& Zou, S. (2015). Effect of customer participation on service outcomes: The moderating role of participation readiness. Journal of Service Research, 18(2), 160-176.

Elliott, R., Fischer, C. T., \& Rennie, D. L. (1999). Evolving guidelines for publication of qualitative research studies in psychology and related ${ }^{\circledR}$ elds. British Journal of Clinical Psychology, 38, 215-229. http://doi.org/10.1348/014466599162782

Frambach, R. T., Fiss, P. C., \& Ingenbleek, P. T. (2016). How important is customer orientation for firm performance? A fuzzy set analysis of orientations, strategies, and environments. Journal of Business Research, 69(4), 1428-1436.

Frow, P., Nenonen, S., Payne, A., \& Storbacka, K. (2015). Managing co-creation design: A strategic approach to innovation. British Journal of Management, 26(3), 463-483.

Fung, A. (2015). Putting the public back into governance: The challenges of citizen participation and its future. Public Administration Review, 75(4), 513-522.

Greer, C. R., \& Lei, D. (2012). Collaborative innovation with customers: A review of the literature and suggestions for future research. International Journal of Management Reviews, 14(1), 63-84.

Grundy, A. C., Bee, P., Meade, O., Callaghan, P., Beatty, S., Olleveant, N., \& Lovell, K. (2016). Bringing meaning to user involvement in mental health care planning: a qualitative exploration of service user perspectives. Journal of psychiatric and mental health nursing, 23(1), 12-21.

Jaakkola, E., Helkkula, A., \& Aarikka-Stenroos, L. (2015). Service experience co-creation: conceptualization, implications, and future research directions. Journal of Service Management, 26(2), 182-205.

Jaakkola, E., Meiren, T., Witell, L., Edvardsson, B., Schäfer, A., Reynoso, J., ... \& Weitlaner, D. (2017). Does one size fit all? New service development across different types of services. Journal of Service Management, 28(2), 329-347.

Jiang, B., \& Chen, C. (2002). A Study of Customer-oriented service culture - concepts and approaches. Research Development and Evaluation, 26(5), 93-101.

Jouny-Rivier, E., Reynoso, J., \& Edvardsson, B. (2017). Determinants of services co-creation with business customers. Journal of Services Marketing, 31(2), 85-103.

Koc, E., Ulukoy, M., Kilic, R., Yumusak, S., \& Bahar, R. (2017). The influence of customer participation on service failure perceptions. Total Quality Management \& Business Excellence, 28(3-4), 390-404. 
INTERNATIONAL JOURNAL OF ACADEMIC RESEARCH IN PROGRESSIVE EDUCATION AND DEVELOPMENT

Vol. 7, No. 3, July 2018, E-ISSN: 2226-6348 @ 2018 HRMARS

Kohli, A. K., \& Jaworski, B. J. (1990). Market Orientation: The Construct, Research Propositions, and Managerial Implications. Journal of Marketing, 54(2), 1-18.

Koskela-Huotari, K., Edvardsson, B., Jonas, J. M., Sörhammar, D., \& Witell, L. (2016). Innovation in service ecosystems - Breaking, making, and maintaining institutionalized rules of resource integration. Journal of Business Research, 69(8), 2964-2971.

Krawczyk, M. (2013). Sources of information for innovative activity of enterprises. Types, Importance, Measurement. Oeconomia Copernicana, (1), 5-18. Retrieved from http://search.proquest.com/docview/1462231635?accountid=27292

Kuusisto, A., \& Riepula, M. (2011). Customer interaction in service innovation: seldom intensive but often decisive. Case studies in three business service sectors. International Journal of Technology Management, 55(1/2), 171. http://doi.org/10.1504/IJTM.2011.041686

Li, Y., Li, G., \& Feng, T. (2015). Effects of suppliers' trust and commitment on customer involvement. Industrial management \& data systems, 115(6), 1041-1066.

Matthing, J., Sandén, B., \& Edvardsson, B. (2004). New service development: learning from and with customers. International Journal of Service Industry Management, 15(5), 479-498. http://doi.org/10.1108/09564230410564948

McColl-Kennedy, J. R., Gustafsson, A., Jaakkola, E., Klaus, P., Radnor, Z. J., Perks, H., \& Friman, M. (2015). Fresh perspectives on customer experience. Journal of Services Marketing, 29(6/7), 430-435.

Morrison, M., Gan, S., Dubelaar, C., \& Oppewal, H. (2011). In-store music and aroma influences on shopper behavior and satisfaction. Journal of Business Research, 64(6), 558-564. http://doi.org/10.1016/j.jbusres.2010.06.006

Mustak, M., Jaakkola, E., Halinen, A., \& Kaartemo, V. (2016). Customer participation management: Developing a comprehensive framework and a research agenda. Journal of Service Management, 27(3), 250-275.

Nica, E. (2015). Public Administration as a Tool of Sustainable Development. Journal of SelfGovernance and Management Economics, 3(4), 30-36.

Noor Zaidi and Siti Arpah (2011) Customer-driven business information provision. RMI, UiTM, Shah Alam (Unpublished)

Nwankwo, S. (1995). Developing a customer orientation. Journal of Consumer Marketing, 12(5), 5-15. http://doi.org/10.1108/07363769510103856

Okello-Obura, \& Matovu, J. (2011). SMEs and Business Information Provision Strategies: Analytical Perspective. Library Philosophy \& Practice, 97-109.

Pinsky, D. (2015). The sustained snapshot: Incidental ethnographic encounters in qualitative interview studies. Qualitative Research, 15(3), 281-295.

Prakash K. Chathoth, Gerardo R. Ungson, Robert J. Harrington, Eric S.W. Chan, (2016) "Cocreation and higher order customer engagement in hospitality and tourism services: A critical review", International Journal of Contemporary Hospitality Management, Vol. 28 Issue: 2, pp.222-245, https://doi.org/10.1108/IJCHM-10-2014-0526

Puga-Leal, R., \& Ormazabal, M. (2017). Service Capability Analysis as a Contribution to CoCreation. In Handbook of Research on Strategic Alliances and Value Co-Creation in the Service Industry (pp. 133-153). IGI Global. 
INTERNATIONAL JOURNAL OF ACADEMIC RESEARCH IN PROGRESSIVE EDUCATION AND DEVELOPMENT

Vol. 7, No. 3, July 2018, E-ISSN: 2226-6348 @ 2018 HRMARS

Raie, M., Khadivi, A., \& Khdaie, R. (2014). The effect of employees' customer orientation, customer's satisfaction and commitment on customer's sustainability. Arabian Journal of Business and Managmenet Review, 4(1), 109-123.

Schemmann, B., Herrmann, A. M., Chappin, M. M., \& Heimeriks, G. J. (2016). Crowdsourcing ideas: Involving ordinary users in the ideation phase of new product development. Research Policy, 45(6), 1145-1154.

Spector, R. (2017). The Nordstrom Way to Customer Experience Excellence: Creating a Valuesdriven Service Culture. John Wiley \& Sons.

Taylor, S. J., \& Bogdan, R. (1985). Introduction to Qualitative Research Methods: The Search for Meaning. Nursing Research (Vol. 34).

Tukker, A., \& Tischner, U. (Eds.). (2017). New business for old Europe: product-service development, competitiveness and sustainability. Routledge.

Tummers, L. L., Bekkers, V., Vink, E., \& Musheno, M. (2015). Coping during public service delivery: A conceptualization and systematic review of the literature. Journal of Public Administration Research and Theory, 25(4), 1099-1126.

Webster, F. E. (1988). The rediscovery of the marketing concept. Business Horizons, 31(3), 2939. http://doi.org/10.1016/0007-6813(88)90006-7

Woodward, C., \& Joseph, S. (2003). Positive change processes and post-traumatic growth in people who have experienced childhood abuse: Understanding vehicles of change. Psychology and Psychotherapy: Theory, Research, and Practice, 76, 267-283. http://doi.org/10.1348/147608303322362497

World Bank. (1991) Managing Development: The Governance Dimension [Online]. Washington D.C.: World Bank. Retrieved from: http://www wds.worldbank.org/external/default/WDS ContentServer/WDS $\mathrm{P} / \mathrm{IB} / 2006 / 03 / 07$ 000090341_20060307104630/Rendered/PDF/34899.pd [Accessed 25 April 2015].

Zhang, Y., \& Wildemuth, B. M. (2016). Qualitative analysis of content. Applications of social research methods to questions in information and library science, 318. 